\title{
Training Funds and the Incidence of Training: The Case of Mauritius
}

\author{
Oluyemisi Kuku, IFPRI \\ Peter F. Orazem, Iowa State University \\ Sawkut Rojid, The World Bank \\ Milan Vodopivec, University of Primorska and International School for Social and Business \\ Studies, Celje \\ January 2015
}

\begin{abstract}
Training funds are used to incentivize training in developing countries, but the funds are based on payroll taxes that lower the return to training. In the absence of training funds, larger, highwage and more capital intensive firms are the most likely to offer training unless they are liquidity constrained. If firms are not liquidity constrained, the fund could lower training investments. Using an administrative dataset on the Mauritius training fund, we find that the firms most likely to train pay more in taxes than they gain in subsidies. The smallest firms receive more benefits than they pay in taxes.
\end{abstract}

JEL: M53; O15; O2; 055

KEYWORDS: training, general skills, firm-specific skills, training fund, externality, crosssubsidy, tax

Corresponding author: Peter F. Orazem, Department of Economics, Iowa State University, Ames, IA, 50011-1070, USA. pfo@iastate.edu (515) 294 8656. Kuku: O.Kuku@cgiar.org Rojid: srojid@worldbank.org Vodopivec: milan.vodopivec@gmail.com.We appreciate numerous suggestions from the referees and financial support from the World Bank. 


\section{Training Funds and the Incidence of Training: The Case of Mauritius}

\section{Introduction}

There are numerous market failures that would lead firms to underinvest in training. One is that training may increase a worker's value not just in the firm that paid for the training but in other firms as well. Consequently, a firm that invests in training risks losing its investment to its rivals. The better strategy may be for the firm to free ride on its rivals' investments by raiding their trained workers without having to invest themselves. The free-rider problem causes all firms hold back on their investments.

A second reason for under-provision is if training is subject to returns to scale. Individual firm training investments will be more costly than if training were provided by a single provider. A third reason is that unlike physical capital, human capital cannot be used as collateral. Firms may face liquidity constraints in training investments if they are unable to borrow against future gains in labor productivity.

Training funds are one approach to address the under-provision of training, practiced in both developing and developed economies. The sectoral training agreements common in Europe allow all the firms using a particular type of skill to agree to pay equally for training through the payroll tax and then share in the benefits of trained workers. The coordination forces all firms to internalize the training externality arising from labor mobility. ${ }^{1}$ In contrast, in developing countries a common training fund usually covers all sectors. ${ }^{2}$ Because these programs are not

\footnotetext{
${ }^{1}$ The earliest training levy/grant programs in Belgium, Cyprus, Denmark, France and the Netherlands began as narrowly focused sectoral training programs in the 1960s and 1970s. See CEDEFOP(2008) for a summary of European training fund programs.

${ }^{2}$ In a recent review, Johanson (2009) lists 62 countries with training funds worldwide. Most of these programs are found in Latin America (17 countries), Sub-Saharan Africa (17 countries), and Europe (14 countries). In contrast, there are only 7 programs in Asia and the Pacific Region. The most typical levy is about $1 \%$ of the wage bill, but with considerable variation from $0.25 \%$ of the wage bill in Uruguay; to $3 \%$ of the wage bill in Bahrain, Jamaica and Senegal; and to $4 \%$ of the wage bill in Burkina Faso. Types of training funded by training funds include external
} 
focused on a common set of skills, they invariably involve cross-subsidization of training intensive firms by nontraining firms, and so the justification for the European training programs does not hold. Nevertheless, these programs could address other possible externalities and constraints: such funds could help to generate increasing returns to scale in the provision of generally valued skills, as well as, by providing a training subsidy, incentivize firms to increase investment in workers in the face of liquidity constraints.

Even if these market failures exist, it is not clear that they are sufficiently large to outweigh the inefficiencies caused by a payroll tax that lowers the return to investment if the tax is borne by the firm. Additionally, costs associated with collecting taxes and administering the training funds are unnecessary if firms would have invested in training without the program. However, past studies have not examined whether these training fund programs are cost effective. Johanson's (2009) comprehensive review of 62 national training funds concluded that despite vast amounts spent on training, evaluation has been largely anecdotal and limited to assessments of outcomes against targeted levels. This is particularly true in developing countries where studies have yet to establish that firms face lower marginal costs of training or increase their training investments as a result of the training funds.

The need for evaluations of training funds is particularly urgent in Sub-Saharan Africa which faces the need to accommodate the fastest growing labor force in the world. There are numerous areas where public dollars could be used to enhance job growth, and so investments in training carry a high opportunity cost. When asked what factors hinder business growth, African firms rank insufficient job skills as $11^{\text {th }}$ most important, behind such factors as transportation,

training such as specialized courses in IT or language provided by training firms; and in-house training provided by enterprises themselves. Training duration typically varies from a few days to several months, but some will cover Master's training that could last two years. 
access to electricity, input costs, access to financing, and political instability (McKinsey and Company, 2012). It is not obvious that training is the best use of scarce resources.

This paper uses the Mauritius Training Fund as a case study of the performance of training funds. We examine whether the firms that engage in training are those that would be predicted to train in a standard Becker (1993) model of training or if the training fund alters the incentives to train. Next, we examine the implied patterns of cross-subsidization from the firms paying into the system to the firms receiving the training subsidies. That analysis shows which industries are taxed in order to subsidize others and whether small firms subsidize large firms or vice versa. Finally, we examine whether there is any evidence that the training raises labor productivity.

We find that the training subsidy does increases training for the smallest firms that would not otherwise train without the subsidy. However, large, capital-intensive, high-wage firms that would be expected to have the greatest incentive to train without the subsidy end up paying more in taxes than they receive in subsidies. Furthermore, the subsidies focus on classroom training that has the lowest returns rather than on in-house training that has the highest returns in evaluations. We conclude that in Mauritius, for medium and large firms, the adverse effect of the tax on training outweighs the incentive effect of the subsidies. As a result, the training fund may well lower rather than raise the incidence of training in the country.

\section{The Mauritius Training Fund}

Following the Human Resource Development Act of 2003, all registered firms in Mauritius are required to pay a training levy. The tax is proportional to the firm's total base wage bill, the aggregate of wages paid workers excluding overtime, bonus and benefits. The 
levy rate was $1 \%$ until 2008 , and increased to $1.5 \%$ since then. However, only one-third of the tax is now used to reimburse training costs and two-thirds goes for unemployment benefits (Parliament of Mauritius, 2008).

The government uses the training fund to reimburse firms for a portion of their training costs. All trainings need to be pre-approved by the Mauritius Qualifications Authority and firms apply for reimbursement after the training is delivered. According to the Training Fund rules, firms can be reimbursed up to ten times the tax they pay into the training fund. The reimbursement rate falls as the total expenditure on training increases, but the reimbursement can still be as high as five times the training levy paid for the most training intensive firms. ${ }^{3}$ The reimbursement rate does not depend on the type of training undertaken.

The stated objectives of the training fund are to (i) promote human resource development in line with national economic and social objectives, (ii) stimulate a culture of training and lifelong learning at the individual, organizational and national levels for employability and increasing productivity; and (iii) provide the necessary human resource thrust for successful transformation of the economy into a Knowledge Economy. Only the last of these is sufficiently concrete to enable an evaluation, suggesting that the program should atypically induce training in the technology sector or other sectors that use information technologies.

Table 1 presents summary information on the percentage of firms providing training by industry and firm size cells. In all 9 sectors, the proportion of firms investing in training increases with firm size. Propensity to train varies by sector between $6-10 \%$ for the smallest firms to $23-47 \%$ for the largest firms. Consistent with the stated objective to encourage the

\footnotetext{
${ }^{3}$ For annual levy up to Rs 20,000, the maximum reimbursement is ten times levy paid; for a levy between Rs 20,000 and Rs 100,000, the maximum reimbursement is either Rs 200,000 plus five times the levy paid over Rs. 20,000 or Rs 300,000, whichever is the lower; for a levy above Rs 100,000 , the maximum reimbursement is Rs 300,000 plus five times the levy paid over Rs.100,000.
} 
growth of the knowledge economy, the probability of training is highest in Information

Technology and Finance. Nevertheless, the training incidence in Mauritius is much lower than that reported for developed economies. For example, in the U.S., over $98 \%$ of firms with 50 or more employees provide training (Frazis, Herz, and Horrigan, 1995).

We also report measures of training intensity for the firms that provided training.

Because of smaller samples, we only report the industry-wide averages. Training intensity, both in hours and costs, varies significantly across sectors. Because workers can engage in multiple types of training per year, we report the averages per employee rather than per trainee session. Firms provided an average of 22 hours of training per employee per year, roughly half the hours training provided by firms in the U.S. (Frazis and Spletzer, 2005; Miller, 2012). ${ }^{4}$ The greatest time investment in training per worker is in transportation at almost 90 hours per employee per year. The least time invested in training is in construction.

The average per employee training cost was almost 60 thousand rupees per employee or roughly $\$ 2,000$ per worker. That amount is consistent with the direct plus indirect training costs per worker in the United States (Miller, 2012). The most costly training was in finance at over $\$ 3.000$ per employee, even though the time invested was modest. Hotels also had relatively expensive training per hour. The relatively large per employee training cost in wholesale and retail trade and in community and social service reflects their relatively large time investment in training.

Nevertheless, the reimbursement rate does not vary much across sectors and firm sizes despite the substantial differences in costs, measured in rupees or trainee time commitments. We computed the ratio of reimbursements received relative to training payments reported for all 27

\footnotetext{
${ }^{4}$ To put the Frazis and Spletzer figures in per employee terms, we took the mean hours per trained worker in theior table 3 and incorporated the 0 hours of training for the $53 \%$ of workers that did not train.
} 
firm size-sector cells. As we see in Table 2, there was a very slight pattern of rising average reimbursement rates by firm size, and only modest variation in average reimbursement rates across sectors. Across the 27 cells, the training fund covered an average of $50-65 \%$ of the reported training costs with the firms covering the rest.

One might expect that the training fund should have induced most firms to invest at least modestly in training every year. Instead, only 9\% of the firms participated in FY2008. The fact that training costs almost as much in Mauritius as in the United States may explain why firms are shy about offering training. Other training costs may also cause firms to shy away from training. Receipt of the training subsidy requires substantial paperwork, use of approved trainers, and prior approval of the training curriculum. The training is also subject to minimum participation of 10 workers if the training is offered in the workplace. These restrictions clearly limit the potential participation of smaller firms that may not have enough workers to train or sufficient expertise to manage the paperwork, consistent with the pattern of training by firm size found in Table 1.

While small firms face disadvantages from participation, large firms also have been slow to respond to the Mauritius training fund. One problem is that the program focuses on reimbursement for formal training with greater restrictions on training offered in firms rather than classrooms. As shown in Figure 1, formal training plus overseas training initially accounted for nearly three-fourths of training reimbursements in the first year after the training fund was implemented. Since then, the formal training share has fallen steadily over time while in-house training increased in importance. ${ }^{5}$ Firms complained that the training provided by institutions was too generic to meet their needs. That assessment is consistent with the findings of Betcherman et al (2004) who found that on-the-job training and in-house training are particularly

\footnotetext{
${ }^{5}$ Courses conducted for employees of one enterprise are considered as in-house training.
} 
effective in evaluations conducted in developed, transition, and Latin American economies while classroom training has mixed or negative outcomes.

If the training fund is eliminating a market failure due to liquidity constraints that constrain firm incentives to train, one would expect the program would have broad participation. Instead, Figure 2 shows that taxes levied on firms typically exceeded the training grants disbursed, so much so that contributions to the training fund were cut in half in FY2009, even as the tax on the wage bill was increased. The World Bank (2011) estimated that no more than $20 \%$ of Mauritian firms had provided formal training that could qualify for reimbursements over the first four years of the program. That percentage is below the $30 \%$ training incidence for SubSaharan Africa reported by Johanson (2009) and well below the training incidence reported for developed countries.

The underutilization of training funds in Mauritius is not unusual. In Costa Rica, Gabon, Togo, and Zimbabwe, underutilized training funds were repurposed to other uses. In Colombia and Venezuela, training funds were used to create a large government training bureaucracy rather than encouraging firm in-house training. That pattern appears to be starting in Mauritius where the number of private training institutions is increasing even as their share of training provision is declining and firms are complaining about their services.

Even if the Mauritius training fund is not fully utilized, it may still increase the propensity to train. To assess that, we need to establish a model of expected training in the absence of the government program. We turn to that next.

\section{Theory}

Becker's (1993) theory of on-the-job training provides a useful framework for our evaluation, allowing us to predict which firms would invest in training under the Mauritius 
training fund program. In Becker's framework, general skills were observable and equally valued across all firms and so firms would only invest in skills that were specific to and hence only valuable in that firm. As demonstrated by Acemoglu and Pischke $(1998,1999)$, the firm might still pay for general training if information asymmetries or other labor market rigidities make workers immobile. Our framework is equally valid regardless of the firm-specific or general nature of the training. ${ }^{6}$ However, the theory does generate estimable conditions under which the training fund will succeed or fail.

A firm's incentive to invest in training depends on the anticipated returns to training compared to the opportunity costs and direct costs of the training. Let $T_{i}$ be a dummy variable that indicates whether the $i^{\text {th }}$ firm invests in training. Training will occur if the expected net return from training $R_{i}$ is positive. Probability that firm $i$ trains is

$\operatorname{Pr}\left(T_{i}=1\right)=\operatorname{Pr}\left(R_{i}>0\right)$

$R_{i}$ will take the form

$$
\begin{aligned}
R_{i}=N_{i} & (\pi-\tau)\left[\left(\sum_{t=1}^{\mathrm{M}}\left(\frac{1}{1+r}\right)^{t} \cdot\left(T_{i} W_{i t}^{T}+\left(1-T_{i}\right) W_{0}^{O}\right)\right]+N_{i}(\pi-\tau)\left(1-T_{i}\right) W_{0}^{O}\right. \\
& -N_{i} T_{i} W_{0}^{O}(1+\tau)+N_{i} T_{i}\left(S_{i 0}^{T}+\varepsilon_{i}^{T}-C_{i 0}^{T}\right)
\end{aligned}
$$

where $M$ represents the firm's time horizon over which it anticipates employing $N_{i}$ workers.

The firm earns a markup $\pi$ on the wages it pays. The firm's cost of labor includes a tax rate, $\tau$. The firm must pay taxes into the training fund, whether or not it trains. If the firm trains, it pays the post-training wage, $W_{i t}^{T}$ for all $t>0$. If the firm does not train, it pays workers a constant base

\footnotetext{
${ }^{6}$ The case for government training subsidy is weakest for firm-specific skills because there is no free rider problem. In addition, the training would only be valued at that specific firm, and so there are no additional cost savings by coordinating training across firms to exploit returns to scale. However, there may still be a public good from government training support if firms face liquidity constraints that prevent them from investing optimally in human capital.
} 
wage, $W_{0}^{O}$ for all $M$ periods. If the firm trains in period 0 , it gets no output in period $O$ but pays the worker's opportunity wage along with the tax levy, $W_{0}^{O}(1+\tau)$.

The remaining terms incorporate firm-specific costs and benefits from training. $C_{i 0}^{T}$ represents the firm's direct cost of training which can vary significantly across firms as we saw in Table 1. $S_{i 0}^{T}$ is the training subsidy the firm can expect from the government which varies by firm size and sector. The firm's average return from training is given by the markup term, $\pi$, but the firm also faces idiosyncratic returns related to the nature of its training opportunities. These positive or negative increments to per worker return to training, $\varepsilon_{i}^{T} \sim N\left(0, \sigma_{\varepsilon}\right)$, are assumed to be known to the firm but not the econometrician.

The firm's marginal net return to training is

$\frac{\partial R_{i}}{\partial T_{i}}=N_{i}(\pi-\tau)\left[\left(\sum_{t=1}^{\mathrm{M}}\left(\frac{1}{1+r}\right)^{t}\right)\left(W_{i t}^{T}-W_{0}^{O}\right)\right]-N_{i}(\pi+1) W_{0}^{O}+N_{i}\left(S_{i 0}^{T}+\varepsilon_{i}^{T}-C_{i 0}^{T}\right) \gtrless 0$

If $\frac{\partial R_{i}}{\partial T_{i}}>0$, the firm should invest in training. If $\frac{\partial R_{i}}{\partial T_{i}}<0$, the firm will not train. Factors that make $\frac{\partial R_{i}}{\partial T_{i}}$ more positive will raise the probability of training. Examining (3), the second term is negative. At the sample mean for $\varepsilon_{i}^{T}$, the third term is also negative because the government does not fully reimburse all training costs. Therefore, a positive net return requires that the first term is positive. That requires that $W_{t}^{T}>W_{0}^{O}$ so that training raises worker productivity. ${ }^{7}$ It also requires that $\pi>\tau$ so that the profit from raising a worker's marginal product exceeds the taxes that would be paid on the resulting wage increases. $\frac{\partial R_{i}}{\partial T_{i}}$ becomes more positive and so likelihood of training increases with increases in the mark-up over wages $\pi$, increases in the training subsidy $S_{i 0}^{T}$, increases in the productivity of training as proxied by the wage gap

\footnotetext{
${ }^{7}$ Training cannot lower productivity from the base level, but it is possible that the training adds no value so that $W_{t}^{T}=W_{0}^{O}$. In that case, the only reason the firm would engage in training is that the subsidy $S_{i 0}^{T}$ is so large that it fully compensates the firm for the lost production while the firm trains.
} 
$\left(W_{i t}^{T}-W_{0}^{O}\right)$, and increases in the unobserved profitability from training $\varepsilon_{i}^{T}$. The probability of training also increases with a lower tax levy imposed on the induced increase in wages, $\tau$; with smaller interest rates that reduce the present value of future returns to training, $r$; and with smaller training costs $C_{i 0}^{T}$.

The theory demonstrates a potential problem with training funds that generate revenues through taxes on wages. Training will raise wages and so the training fund policy taxes the return on training even as it lowers training costs. There is no guarantee that the policy will raise aggregate training in the economy. The training fund will be most effective when firm's face liquidity constraints as represented by high interest rates, $r$. The reason is that $\frac{\partial^{2}\left(\frac{\partial R_{i}}{\partial T_{i}}\right)}{\partial \tau \partial r}>0$ : the tax does not affect the present value of training as much when the firm is discounting the future more heavily. However, if liquidity constraints are modest and so interest rates are low, the tax levy becomes more costly, lowering the probability that the training fund increases training.

If the costs of training $C_{i 0}^{T}$ and the subsidy $S_{i 0}^{T}$ are constant and do not vary with firm size, equation (3) implies that there will be no size-bias in the incidence of training. In other words, $C_{i 0}^{T}$ and/or $S_{i 0}^{T}$ must be nonlinear in $N$ to generate the size-bias in the training data we observed in Table 1. Either or both of the following specifications could generate the rising incidence of training as firm size increases

$C_{i 0}^{T}=\frac{c_{0}}{N_{i}}+C\left(N_{i}\right) ; C^{\prime}\left(N_{i}\right) \leq 0$

$S_{i 0}^{T}=S\left(N_{i}\right) ; S^{\prime}\left(N_{i}\right) \geq 0$

Equation (4A) suggests that firms face a fixed cost of participation due to paperwork involved in applying or validating the training and providing the required accounting to the government. Average cost of training falls with the size of the firm because these fixed costs are 
spread over a larger number of trainees and also because there may be increasing returns to training such that $C^{\prime}<0 .{ }^{8}$ Even if the marginal cost of training is constant as $N_{i}$ increases, there will be falling average cost of training as firm size rises. As for $S^{\prime}\left(N_{i}\right) \geq 0$, the requirement that the firm have a minimum number of trainees to qualify for a subsidy generates a subsidy that increases in $N .^{9}$

The theory suggests that there should be rising incidence of training as firms increase in size, as the subsidy increases in value, as training costs decrease, and as wages rise relative to the untrained wage. These predictions lead directly to the empirical specification we employ in the next section.

\section{Empirical specification}

The theory suggests two specifications. The first treats training as a dichotomous variable. Using (3), we infer that $T_{i}=1$ if

$I=(\pi-\tau)\left[\left(\sum_{t=1}^{\mathrm{M}}\left(\frac{1}{1+r}\right)^{t}\right)\left(W_{i t}^{T}-W_{0}^{O}\right)\right]-(\pi+1) W_{0}^{O}+S_{i 0}^{T}-C_{i 0}^{T}>-\varepsilon_{i}^{T}$

If we approximate the index function $I(\cdot)$ by its reduced form and divide by the standard deviation in $\varepsilon_{i}^{T}$, we have

$T_{i}=1$ if $\frac{I\left(\pi, W_{i t}^{T}, W_{0}^{O}, \tau, C_{i 0}^{T}, S_{i 0}^{T}, N_{i}\right)}{\sigma}>\frac{-\varepsilon_{i}^{T}}{\sigma}$

$T_{i}=0$ otherwise

As the unobserved return to training is assumed to be normally distributed, equation (5) defines a probit equation. If instead, we have a continuous measure of training intensity, then the reduced form will be

\footnotetext{
${ }^{8}$ Black et al (1999) show that there are economies of scale in training that favor large firms.

${ }^{9}$ We can redefine $T_{i}$ as training intensity such that $0 \leq T_{i} \leq 1$. That would make sense, for example, if firms invested between 0 and $100 \%$ of the workers' time in the first period in training. In that case, firms that train will invest optimally by setting $\frac{\partial R_{i}}{\partial T_{i}}=0$ in (3). For an interior solution, firms must face increasing costs of training or decreasing returns to training.
} 
$T_{i}=f\left(\pi, W_{i t}^{T}, W_{0}^{O}, \tau, C_{i 0}^{T}, S_{i 0}^{T}, N_{i}, M, \varepsilon_{i}^{T}\right)$

which we can approximate using ordinary least squares.

In our application, the training levy tax rate $\tau$ is the same for all firms and we assume the markup over the wage $\pi$ is also fixed in expectation across firms. The base wage $W_{0}^{O}$ should also be the same across firms in the same industry. Mauritius is a small island economy, and so it is logical to assume that worker mobility will equalize sectoral base wages throughout the island. Consequently, sectoral variation in $W_{0}^{O}$ can be controlled using sector-specific dummy variables. The remaining observable explanatory variables in (5) and (6) that vary across firms include $W_{i t}^{T}, C_{i 0}^{T}, S_{i 0}^{T}$, and $N_{i}$.

\section{Data}

Our data source is an administrative data set that includes training levy, firm size and firm sector information for the universe of all registered firms in Mauritius in 2007. The data set also includes accounting data for about $30 \%$ of the firms in 2007 . The data are sufficient to allow us to approximate the information we need to evaluate the determinants of training in Mauritius.

\section{Endogenous Variables}

We have two measures of $T_{i}$ available in the data set:

Training Incidence: A dummy variable equal to 1 if the firm trained in 2007. Only 9\% of the firms reported training expenditures in 2007.

Training Intensity: The log of total training expenditures per employee in 2007. This measure presumes that when a large firm only trains a single worker, that is a less intensive training investment than if a small firm trains its lone employee. 
Our measure of training includes primarily the formal training that would involve an outside training firm or dedicated human resources staff person who would provide training that was preapproved for the subsidy by the Mauritius Qualifications Authority. Informal training such as that provided on-the -job or by coworkers will not be included in the expenditure data on training. As a result, we will measure the amount of total training with error. That will lower the goodness-of-fit measures but should not cause systematic errors in the estimated coefficients if, as is likely, formal and informal training are positively correlated. Nevertheless, if the errors are perverse, it may cause coefficient estimates that will be inconsistent with the expected relationships of expected costs and returns on training investments.

\section{Exogenous Variables}

The key regressors we require are measures of firm wages, training costs and the anticipated subsidy. The Mauritius administrative data did not include individual wages or the wage bill for the firm. However, it did include a measure of the aggregate training levy paid by the firm. Regardless of whether they train or not, each firm pays the training levy used to subsidize firm training. The levy is proportional to the firm's base wage bill which is total compensation excluding overtime, bonuses and benefits. That means that the training levy equals $\tau N_{i} \bar{W}_{l}$ where $\tau$ is the tax rate, $N_{i}$ is the number of firm employees, and $\bar{W}_{l}$ is the average wage in the firm in year $t$. In $\log$ form, $\ln \left(\frac{\tau N_{i} \overline{W_{l}}}{N_{i}}\right)=\ln \left(\tau \overline{W_{l}}\right)=\ln (\tau)+\ln \left(\overline{W_{l}}\right)$. Because the training levy, $\tau$, is the same for all firms, its effects will be captured in the constant term. As a result, all of the variation in $\ln \left(\tau \bar{W}_{l}\right)$ is due to $\ln \left(\overline{W_{l}}\right)$. Because sector dummies controls for variation in $W_{0}^{O}$, the coefficient on $\ln \left(\tau \bar{W}_{l}\right)$ is interpretable as the elasticity of training with respect to $\left(W_{i}^{T}-W_{0}^{O}\right)$, a proxy of the anticipated return to training. 
The Mauritius administrative data provide information on the total cost of training including firm payments and the government subsidy for all firms that participate in the program. Because the firm's expenditure on training is endogenous, we require a measure of training costs that are outside the control of the firm. We assume that the price of training is driven by the type of training required in firms of similar size in the same industry. That suggests measuring the price of training as the average hourly cost per trainee for all firms investing in training in a given firm size and sector cell. The log of this average training cost per hour is used as the expected training cost, $C_{i 0}^{T}$ for all firms in each of the 27 firm size-sector cells we show in the first three columns of Table $1 .{ }^{10}$ This strategy increases in validity with the number of firms and the variance of costs across firms within each size-sector cell. While the results appear sensible, it is prudent to interpret the results as correlational rather than causal.

We use a similar strategy to estimate the expected subsidy in each of the 27 cells. For each company receiving a subsidy in 2007 , we compute the ratio of training grants received by the company to the firm's total expenditures on training. A small fraction of firms had ratios greater than 1. Since firms should only get back a fraction of their training costs, we expect this value to be less than one, and therefore set any values greater than one to one. Expected subsidy

\footnotetext{
${ }^{10} \mathrm{It}$ is common to use means as instruments for individual variables to resolve possible endogeneity problems, as in using average tax rates as instruments for marginal tax rates (Royalty, 2000). In our context, consider the training price faced by firm $i$ in cell $j, P_{i j}$. Then consider the mean price across the $n_{j}$ firms in that cell that train. The mean price conditional on choosing to train is

$\mu_{j}=\frac{\sum_{i=1}^{n_{j}} P_{i j}}{n_{j}}$

The actual price paid by the firm can be written $P_{i j}=\mu_{j}+\varepsilon_{i j}$

The error term, $\varepsilon_{i j}$ will contain the endogenous component of the price. By construction, the mean price in the cell is uncorrelated with the deviation from the mean, $\varepsilon_{i j}$. The validity of this strategy increases with heterogeneity in training prices across firms within the cell and with the number of firms in the cell.
} 
is measured by the mean across all training firms in the size-sector cell. Because these values vary between zero and one we left these as rates rather than converting to logs. ${ }^{11}$

A large literature suggests that there is more need for training in larger firms with more complex production processes and internal labor markets. ${ }^{12}$ In addition, returns to scale in training may give larger firms a cost advantage in training provision (Black et al, 1999). Our firm size measure is total employment $N_{i 0}$ in $\log$ form. ${ }^{13}$

Capital and skill are presumed to be complements in production, and so training is believed to be most important in firms with more complex production processes. Therefore, we include a measure of firm capital $K_{i o}$ to control for heterogeneity in training needs across firms. We only have capital asset measures for 4013 firms and so we use the log of the mean value per firm in each size-sector cell as the common measure for all firms in the cell. Inclusion of capital implicitly places the training decision into the short-run where plant size and equipment are fixed.

\section{Results}

\section{Training incidence and intensity}

\footnotetext{
${ }^{11}$ As many of the values are close to zero, taking the log led to very large negative values for some and values close to zero for others, and so the log tended to exaggerate outliers. In addition, because for numbers close to zero, $\ln (1+x) \rightarrow x$, leaving these values in rates did not depart much from the log transformation applied to the other measures.

${ }^{12}$ Doeringer and Piore (1985) showed how firm size led to the creation of internal labor markets, increased firm training, and lower worker mobility. Oi and Idson's (1999) review of the literature shows that worker mobility is inversely related to firm size. Black et al (1999) show that the incidence of training rises with firm size because large firms have a cost advantage in offering training. Acemoglu and Pischke $(1998,1999)$ argue that asymmetric information on worker productivity leads to worker immobility that increases firm incentive to train. The asymmetric information they discuss is likely to be more important in large firms.

${ }^{13}$ While it is natural to use workforce size as a measure of scale, employment is jointly determined with training, and endogenous. Consequently, we replicated our results by excluding the employment measure. The other coefficients were not sensitive to the inclusion or exclusion of employment and so we opted for inclusion to more closely fit the theoretical formulation implied by equations (5-6).
} 
We report two specifications of the training equation in Table $3 .{ }^{14}$ The results are quite consistent with one another, whether training is measured as a dichotomous variable or as a per worker investment. The results are also consistent with the theoretical predictions implied by equation (3): factors that raise the expected net return on training increase the likelihood that the firm invests. Noting that sector-specific dummy variables are used to fix the value of the base wage, $W_{0}^{O}$, a $1 \%$ increase in the post-training wage relative to the base wage raises the probability of training by 0.055 and training intensity by $0.5 \%$. Recall that in the Becker framework, the firm's return to training is proportional to $\left(W_{i t}^{T}-W_{0}^{O}\right)$, and so higher worker returns in the form of higher wages signal that the firm is making a higher return as well. Training propensity and intensity also increases modestly with firm capital intensity and firm size as measured by the number of employees, consistent with the presumptions that training is subject to scale economies and that capital and skill are complements.

Both training incidence and training intensity are very sensitive to expected subsidy, which we measured by the average fraction of training cost reimbursed by the training fund for the same size-sector cell. Interestingly, expected training costs do not significantly affect the probability of training. That suggests that expected training costs are not an impediment to training, at least in the range of training costs faced by firms in Mauritius. Taking the subsidy and cost results together, we can conclude that on the margin, firms that would not have invested in training without the training fund do invest with the promise of training subsidies. Without the subsidy, training would be concentrated in the largest, capital intensive and skill intensive firms.

\footnotetext{
14 The goodness of fit is low, but our dependent variable is whether the firm invested in training in one particular 12 month period rather than the more theoretically appropriate measure which would be whether the firm ever engaged in training. We note that $20 \%$ of Mauritius firms train, but only $9 \%$ of them trained during our one-year window, an indication of considerable noise in the dependent variable. However, with the huge sample size, we were able to derive reasonable coefficients despite the noisy training indicators.
} 
None of the industry dummy variables are statistically significant individually or jointly. Outside the incentive offered by the subsidy, there is no evidence that the government favors one sector over another. Indeed, the proportional subsidy reported in Table 2 shows very consistent reimbursement rates across sectors and firm sizes. Because training was supposed to target information technologies, these results suggest that the apparent bias toward information technology firms we observed in Table 1 exists because those firms have a greater need to train even without the training fund and not because the training fund is atypically raising training incentives for information technology firms.

The estimated results are quite similar between the two sets of training investment measures. Given the low incidence of training, it is plausible that the training fund only influences the extensive margin (whether or not to train) rather than the intensive margin (how much to invest in training). We reestimated the training intensity equation over the sample of training firms, in effect conducting the conditional effect of the training fund on the amount of training. None of the first five variables that represent the key factor s influencing the returns to training in equation (6) retained significance, suggesting that the training fund primarily influences who trains and not how much to invest in training. ${ }^{15}$

All firms face the same marginal tax on wages and so we cannot estimate the impact of the training tax levy on training investments. The question remains as to whether the training fund increases the incidence of training through the subsidy or lowers the incidence of training because of the tax. The consistent pattern of tax levy receipts exceeding disbursements seen in Figure 2 suggests that the net effect may be to reduce training. We explore that question next.

\section{Cross-subsidization in the Mauritius training fund}

\footnotetext{
${ }^{15} \mathrm{We}$ thank the referees for suggesting this extension.
} 
Because all firms face the same tax rate, we have only limited ability to assess whether the training fund actually increased training incidence. However, we can illustrate how the training fund reallocates resources by atypically taxing some firms and atypically subsidizing others. Table 4 divides the firms into the 27 firm size by industry cells. For each cell, we compute the total training levy paid by firms in the cell, the total subsidies received by firms in the cell, and the ratio of the benefits received to the taxes paid. Ratios above one indicate that the cell group received more in benefits than it paid in taxes while ratios less than one indicate the cell paid more in taxes than it received in training subsidies. ${ }^{16}$ We also report the fraction of firms in each cell that engaged in training.

The results show a surprising result: the pattern of cross subsidization is from large to small firms. While small firms are not likely to train in the absence of the training fund, as shown in the results from Table 3, the training fund grants more in subsidies to small firms than they pay in taxes. The cross subsidization from large to small firms occurs in every sector. This might be according to the stated public interest if the training fund were atypically targeting small IT firms. However, the largest ratios are not in the targeted information sectors, but in agriculture, wholesale and retail trade and transportation.

Moving up the size distribution, intermediate sized firms are more likely than small firms to invest in training, but only in information technology is the ratio of subsidy to training levy larger than it was for the smallest firm. Finance, hotels and information technology are the three sectors that received more in subsidy than they paid in taxes.

Curiously, it is the largest firms that should have the greatest incentive to train without the subsidy. However, these are the firms that face the highest increased tax levy from training. Table 4 shows that large firms pay more in taxes than they receive in benefits in every sector but

\footnotetext{
${ }^{16} \mathrm{We}$ also computed cell values in per worker and per firm terms. The ratios were virtually identical.
} 
Finance, the sector with the highest training costs in Table 1. In fact, Finance is the only sector that systematically received more in benefits than it paid in taxes at all firm size cells, meaning that the training fund shifts resources from low cost training sectors toward the highest cost training sectors. In every sector but Finance, the ratio of benefits to taxes paid is lower for the largest firms than for the intermediate or small firms, and so the training fund tends to shift resources away from the largest firms that have the highest propensity to train in every sector.

Together, Tables 3 and 4 imply the Mauritius training fund alters firm incentives to train but it does so by taxing the firms with the comparative advantage in training in order to subsidize the firms with the least to gain from training. Coupled with the finding in Figure 2 that the training fund takes in more in taxes than it pays out in subsidies, it seems that the net effect may well be to lower the returns to training for large firms through the tax more than it lowers the marginal cost of training as would be the case if the presumed liquidity constraints on large firms were not severe. It does raise the incidence of training in the smallest firms that may indeed face liquidity constraints on training. Whether this is a general pattern of training funds in developing countries that tax firm returns to training in order to generate funds used for training subsidies is unclear, but the Mauritian policy is not dissimilar to the most commonly used training funds in Africa and Latin America. Our results suggest that the policy may be counter-productive.

\section{Training effects on firm output and growth}

We have only limited ability to examine whether training actually raises labor productivity, and so we offer these estimates as suggestive. Training intensive firms should have higher current productivity. Moreover, if the training fund is resolving a market failure that caused firms to underinvest in training, we should find that the training firms will be growing 
faster than others as a consequence of the efficiency gains from moving from inefficient to efficient resource allocations.

We investigate these questions by embedding the firm's training investment in a standard Cobb Douglas production function.

$\ln Q_{i t}=\alpha_{0}+\alpha_{K} \ln K_{i t}+\alpha_{N} \ln N_{i t}+\alpha_{T} \ln T_{i}+X_{i t}^{\prime} \beta+\varepsilon_{i t}$

Our measure of output is total revenue reported in 2007. For this application, we need to use the actual capital measure and so we can only estimate the production function for about one-third of the firms.

For this application, we use the continuous measure of training, $\ln T_{i}$, as defined by the right-hand columns in Table 3. Note that we need to use predicted values of training to generate an expected level of training given the firm's observable attributes. The reason is that any one year's training level measures the long-run level of training investment with considerable error due to random labor turnover that changes the fraction of employees requiring training from one year to the next. This measurement error was of less concern when training was the dependent variable, but measurement error will be more problematic when used as a regressor. A standard method to correct for measurement error is to use instruments to identify the true components of training, using size-sector expected training cost and expected training subsidy and the firm baseline wage level as instruments. In our context, the predicted training level will reflect the long term relationships between firm attributes, taxes subsidies, and propensities to train. The predicted training value also serves as the instrumented measure of the endogenous training decision. The exclusion test on firm wages, expected training cost and training subsidy in Table 3 has an F-statistic of 30.4, well above the critical value in the Stock et al (2002) test for weak instruments. Nevertheless, the validity of these instruments hinges on whether cell means 
adequately correct for endogenous prices as discussed in footnote 10, and so the results may be better interpreted as correlational rather than causal.

The growth equivalent formulation of (7) is used to examine if training firms grow faster than other firms as would be expected if these firms inefficiently underinvested in training in the past due to liquidity constraints. We specify firm growth by

$\ln \frac{Q_{i t+1}}{Q_{i t}}=\gamma_{0}+\gamma_{K} \ln K_{i t}+\gamma_{N} \ln N_{i t}+\gamma_{T} \ln T_{i}+X_{i t}^{\prime} \theta+\epsilon_{i t}$

Equation (8) is estimated using two alternative outcome measures:

Log Wage Bill Growth: The difference in logarithms of the total levy paid between 2007 and 2008 will be proportional to the growth in the wage bill. We use 2007 measures of capital, labor and training as regressors.

Log Employment Growth: The difference in logarithms of the number of employees between 2007 and 2008.

We report these regressions in Table 5. The production function estimates suggest that a 10 percent increase in training intensity increases current output by 4.2 percent. However, while the coefficient on training intensity suggests that training firms grow more rapidly than nontraining firms as would be expected if they were progressing from inefficient toward efficient resource allocations, the estimate fails standard significance levels. We also repeated estimation of equation (7) using sector level training measures to test for possible spillover benefits from training firms to nontraining firms in the same sector. Sector level training measures did not have a significant impact on output.

These tests are merely suggestive. More definitive conclusions would require a longer longitudinal record on training and nontraining firms to see if our cross-sectional production function estimates and growth equations hold up over longer horizons. Nevertheless, taken at 
face value, these results do not suggest evidence of improving resource allocation or spillover benefits that would support using a training fund to remove presumed market failures in training investment. It does appear that training raises worker productivity, but the benefits of the training are largely confined to the firm providing the training.

\section{Conclusions and recommendations}

The Mauritius training program is aimed at encouraging firm training by imposing a levy on all firms and then reimbursing them a percentage of the expenses paid for some types of training. The levy is based on the firm's wage bill, meaning that the largest taxes are paid by firms with the most employees and/or that pay the highest wages, the firms that have the highest return to training in the absence of the program. The tax lowers incentive to train, even as the subsidy raises the incentive to train. Our results show that the factors that should increase the incentives to train in the absence of the training fund behave as expected and that training costs do not serve as an impediment to training. While the subsidies do raise the likelihood of training for firms that would not have trained otherwise, the greatest effect is on the smallest firms. As a result, the program disproportionately taxes the largest and most capital intensive firms that would be most likely to train without the program, and disproportionately benefits the smallest firms that would have the least incentives to train.

One problem is that the training subsidies target classroom skills such as those provided by domestic of foreign training firms and graduate programs and not training provided on-thejob or in-house. Evaluations in both developed and developing countries have found greater benefits from on-the-job training rather than the classroom training favored by the Mauritius training fund. If the performance of the training fund is to be improved, it should target the type of training that is most useful in its absence - training specific to the firm. 
If more general skills are to be offered, it may be useful to follow the sectoral training model used in Europe in which the firms within a specific sector pool resources to invest in skills uniquely required by firms in the sector with the government serving in a coordinating role. That would mean that firms are jointly incorporating the externality associated with private training investments that lead to free-rider problems and underinvestment. That also means that firms in the nontraining sectors of the economy will not have to cross-subsidize the training firms. It is also more likely that targeted training programs aimed at producing general skills in short supply for a large number of firms will benefit from lower costs of training made possible by the returns to scale from training provision that is not possible when individual firms are engaged in that training.

However, another option is to eliminate the training fund program altogether. As shown in the theory, the training fund is most effective when there are liquidity constraints on firms. There is no evidence that the largest and most capital intensive firms in Mauritius suffer from liquidity constraints, and as a result, theory predicts that the negative incentive effects of the tax outweigh the positive effects of the subsidy. As a result, the training fund may well lower the overall incidence of training, consistent with the result in Figure 2 that the program takes in more in taxes than in pays out in subsidies. It is virtually certain that there are alternate uses of these public funds that would produce a better return. 


\section{Bibliography}

Acemoglu, Daron and Jorn-Steffen Pischke. 1998. "Why Do Firms Train? Theory and Evidence.” The Quarterly Journal of Economics 113(1): 79-119.

Acemoglu, Daron and Jorn-Steffen Pischke. 1999. Beyond Becker: Training in Imperfect Labour Markets." The Economic Journal 109(453): F112-F142.

Becker, Gary S. 1993. Human Capital: A Theoretical Analysis with Special Reference to Education, $3^{\text {rd }}$ Edition. Chicago: University of Chicago Press.

Betcherman, Gordon, Karina Olivas, and Amit Dar. 2004. "Impacts of Active Labor Market Programs: New Evidence from Evaluations with Particular Attention to Developing and Transition Countries." Social Protection Discussion Paper Series \#0402. The World Bank.

Black, Dan A., Brett J. Noel and Zheng Wang. 1999. "On-the-Job Training, Establishment Size, and Firm Size: Evidence for Economies of Scale in the Production of Human Capital." Southern Economic Journal 66(1): 82-100.

Card, David, Jochen Kluve and Andrea Weber. 2010. “Active Labour Market Policy Evaluations: A Meta Analysis.” The Economic Journal 120(548):F452-F477.

(CEDEFOP) European Centre for the Development of Vocational Training. 2008. Sectoral Training Funds in Europe. Luxembourg: Office for Official Publications of the European Communities.

Doeringer, Peter B. and Michael J. Piore. 1985. Internal Labor Markets and Manpower Analysis Armonk, NY: M.E. Sharpe.

Frazis, Harley J., Diane E. Herz, and Michael W. Horrigan. 1995. "Employer-provided training: results from a new survey." Monthly Labor Review 118 (5) 3-17.

Frazis, Harley J., and James R. Spletzer. 2005. "Worker training: what we've learned from the NLSY79." Monthly Labor Review 128 (2): 48-58.

Heckman, James J., Robert J. Lalonde and Jeffrey A. Smith. 1999. "The Economics and Econometrics of Active Labor Market Programs." in Ashenfelter and Card eds. Handbook of Labor Economics Vol 3A, Chapter 31. Amsterdam: Elsevier Science, B.V.

Johanson, Richard. 2009.A Review of National Training Funds. World Bank SP Discussion Paper 52187. (November).

McKinsey and Company. 2012. Africa at Work: Job Creation and Inclusive Growth (August).

Miller, Laurie. 2012. 2012 State of the Industry report: Organizations continue to invest in workplace learning. American Society for Training \& Development. 
OECD.1994. The OECD Jobs Study. Evidence and Explanations. Paris: OECD.

OECD.2006. Employment Outlook. Paris:OECD.

Oi, Walter y. and Todd L. Idson. 1999. "Firm Size and Wages." ." in Ashenfelter and Card eds. Handbook of Labor Economics Vol 3B, Chapter 33.Amsterdam: Elsevier Science, B.V.

Parliament of Mauritius. 2008. Employment Rights Act 2008.

Royalty, Anne Beeson. 2000. Tax preferences for fringe benefits and the health insurance offered by employers. Journal of Public Economics 75(2): 209-277.

Stock, James H., Jonathan H. Wright and Motohiro Yogo. 2002. A survey of weak instruments and weak identification in generalized method of moments. Journal of Business and Economic Statistics, 20(4): 518-529.

World Bank. 2011. Skills Development and Technology Absorption in Mauritius. Report No. 62213-MU. (May). 
Figure 1: Distribution of training grants by type of training in Mauritius, FY2005 and FY2009

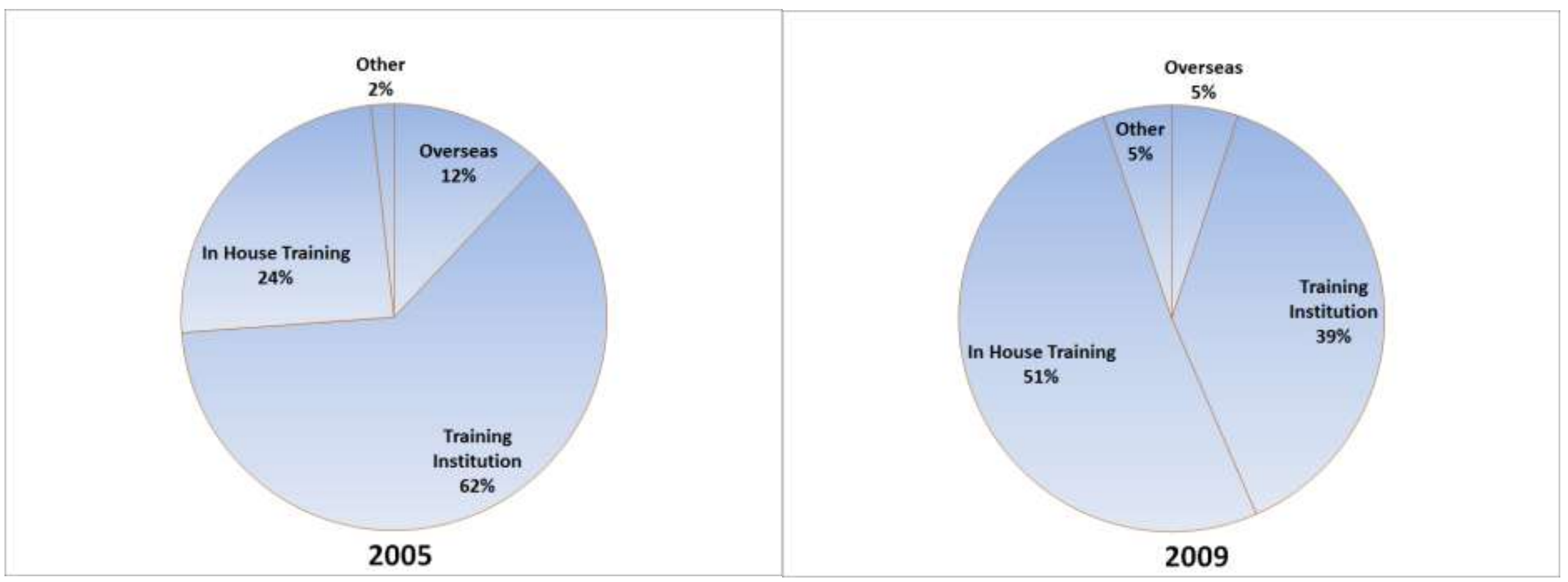

Source: Authors' compilation of data provided by the Mauritius Human Resource Development Council. Other training includes reimbursement for domestic Master's training, for hiring foreign trainers, and for other training not elsewhere classified. 
Figure 2: Tax Levy Receipts and Disbursements (in million Mauritian rupees) of the Mauritius Human Resource Development Council's Training Grant System, FY1989-2010

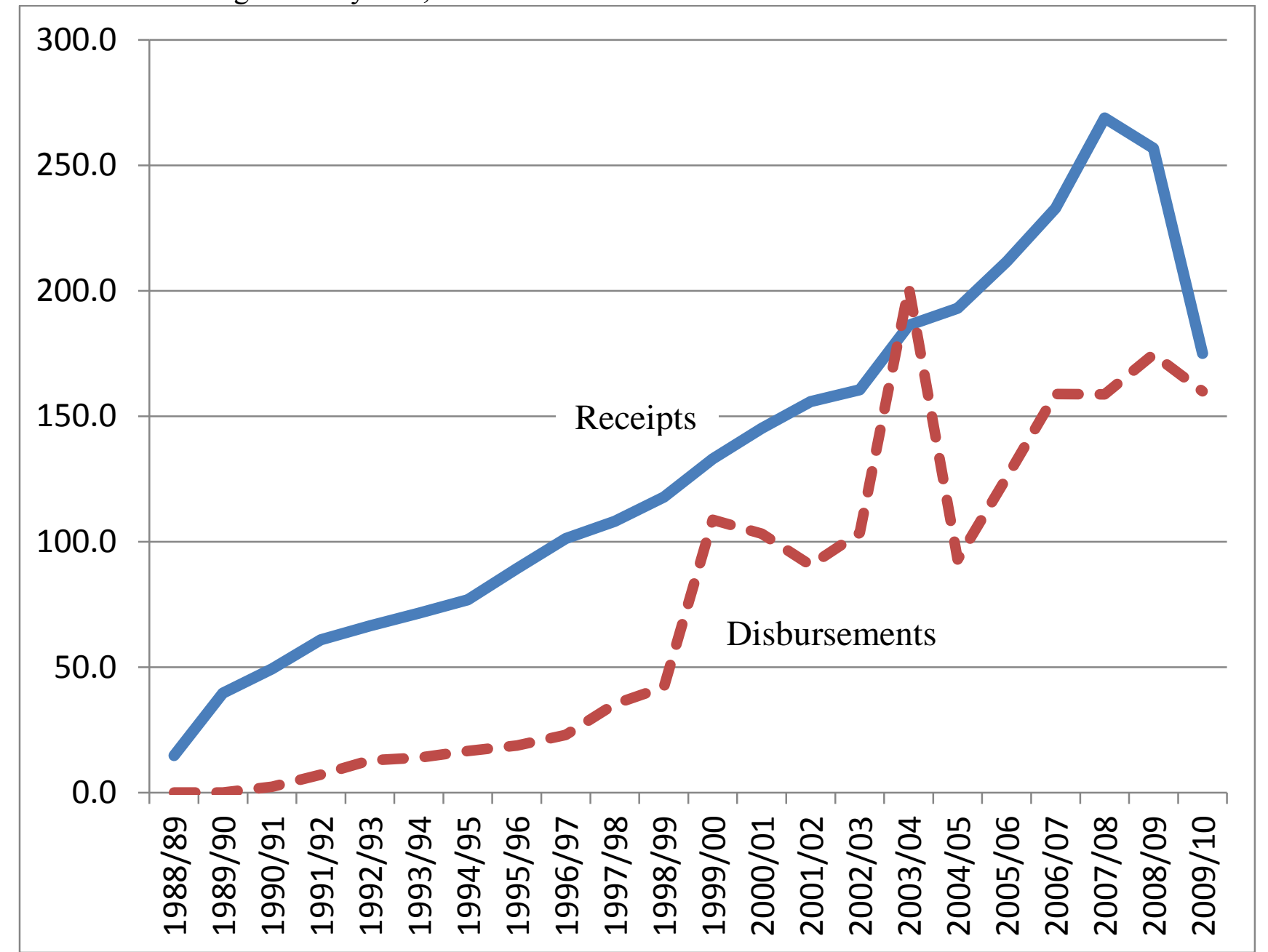

Source: Authors' compilation of data provided by the Mauritius Human Resource Development Council. 
Table 1: Averages of firm propensity to train and training intensity conditional on training, by sector and firm size, Mauritius, $2007 / 2008$.

\begin{tabular}{|c|c|c|c|c|c|c|}
\hline \multirow[b]{2}{*}{ Sector } & \multicolumn{4}{|c|}{ Training Incidence $(\% \text { of firms })^{a}$} & \multicolumn{2}{|c|}{ Training Intensity $^{b}$} \\
\hline & $\begin{array}{c}\text { Small } \\
\text { 1-9 workers } \\
\end{array}$ & \begin{tabular}{|c|} 
Medium \\
10-50 workers \\
\end{tabular} & $\begin{array}{c}\text { Large } \\
>\mathbf{5 0} \text { workers } \\
\end{array}$ & Overall means & $\begin{array}{c}\text { Rupees/Employee } \\
(, 000)\end{array}$ & $\begin{array}{c}\text { Hours/ } \\
\text { Employee }\end{array}$ \\
\hline Agriculture & $5.8 \%$ & $10.4 \%$ & $33.3 \%$ & $8.2 \%$ & 36.5 & 12.7 \\
\hline Manufacturing and & & & & & & \\
\hline Textiles & $6.2 \%$ & $10.9 \%$ & $28.0 \%$ & $10.3 \%$ & 27.6 & 11.0 \\
\hline Wholesale and retail & $6.2 \%$ & $11.0 \%$ & $40.7 \%$ & $8.0 \%$ & 67.3 & 34.2 \\
\hline Community, social and & $67 \%$ & $173 \%$ & $205 \%$ & $920 \%$ & 664 & 355 \\
\hline $\begin{array}{l}\text { Otner services } \\
\text { Construction }\end{array}$ & $\begin{array}{l}0.1 \% \\
5.4 \%\end{array}$ & $\begin{array}{l}17.3 \% \\
9.1 \%\end{array}$ & $\begin{array}{l}29.5 \% \\
27.5 \%\end{array}$ & $\begin{array}{l}9.2 \% \\
7.2 \%\end{array}$ & $\begin{array}{l}00.4 \\
24.6\end{array}$ & $\begin{array}{l}35.5 \\
8.8\end{array}$ \\
\hline Finance & $10.2 \%$ & $25.7 \%$ & $29.3 \%$ & $14.9 \%$ & 103.2 & 20.0 \\
\hline Hotels & $5.6 \%$ & $15.4 \%$ & $25.6 \%$ & $9.2 \%$ & 45.2 & 16.4 \\
\hline Information technology & $7.4 \%$ & $23.9 \%$ & $46.7 \%$ & $13.6 \%$ & 28.8 & 17.2 \\
\hline Transport & $6.5 \%$ & $17.1 \%$ & $22.9 \%$ & $8.4 \%$ & 26.5 & 90.5 \\
\hline Total & $6.4 \%$ & $14.3 \%$ & $29.0 \%$ & $9.1 \%$ & 59.7 & 22.1 \\
\hline Sample size & 13403 & 13403 & 13403 & 13403 & 1018 & 1018 \\
\hline
\end{tabular}

Source: Authors' computation based on the Mauritius training and firm characteristics data set, 2007.

${ }^{a}$ Numerator includes firms that either trained only in 2007 or in both 2007 and 2008. Denominator includes the universe of all registered firms in the sector.

${ }^{b}$ Average value of firms in the sector that engaged in training in 2007 or in both 2007 and 2008. The average includes only those firms that reported the total hours of training and the amount spent on training. 
Table 2: Ratio of Subsidy Received Relative to Total Training Costs Conditional on Receiving a Subsidy, By Firm Size and Sector*

\begin{tabular}{l||c||c||c||c}
\hline Sector & $\begin{array}{c}\text { Small 1-9 } \\
\text { workers }\end{array}$ & $\begin{array}{l}\text { Medium 10-50 } \\
\text { workers }\end{array}$ & $\begin{array}{c}\text { Large }>\mathbf{5 0} \\
\text { workers }\end{array}$ & Total \\
\hline \hline Agriculture & $59.1 \%$ & $57.9 \%$ & $60.5 \%$ & $\mathbf{5 9 . 2 \%}$ \\
$\begin{array}{l}\text { Manufacturing and } \\
\text { textiles }\end{array}$ & $55.6 \%$ & $55.0 \%$ & $56.5 \%$ & $\mathbf{5 5 . 8 \%}$ \\
Wholesale and retail & $56.0 \%$ & $54.9 \%$ & $53.4 \%$ & $\mathbf{5 5 . 4 \%}$ \\
Community, social and & $53.2 \%$ & $53.8 \%$ & $60.1 \%$ & $\mathbf{5 4 . 4 \%}$ \\
other services & & & & \\
Construction & $52.1 \%$ & $53.9 \%$ & $65.0 \%$ & $\mathbf{5 4 . 9 \%}$ \\
Finance & $55.0 \%$ & $60.3 \%$ & $55.4 \%$ & $\mathbf{5 6 . 8 \%}$ \\
Hotels & $55.1 \%$ & $50.4 \%$ & $56.0 \%$ & $\mathbf{5 3 . 9 \%}$ \\
Information technology & $54.9 \%$ & $55.5 \%$ & $60.8 \%$ & $\mathbf{5 6 . 2 \%}$ \\
Transport & $55.1 \%$ & $56.8 \%$ & $56.1 \%$ & $\mathbf{5 5 . 7 \%}$ \\
\hline \hline Total & $\mathbf{5 5 . 1 \%}$ & $\mathbf{5 5 . 5 \%}$ & $\mathbf{5 7 . 4 \%}$ & $\mathbf{5 5 . 6 \%}$ \\
\hline Sor & & & & \\
\hline
\end{tabular}

Source: Authors' computation based on the Mauritius training and firm characteristics data set, 2007.

*Ratio computed as reimbursement received relative to payments made to the trainer. 
Table 3: Regressions explaining training intensity and training probability

\begin{tabular}{|c|c|c|c|c|c|c|}
\hline & \multicolumn{3}{|c|}{ Training Incidence } & \multicolumn{3}{|c|}{ Training Intensity } \\
\hline & $\begin{array}{c}\text { Marginal } \\
\text { effect }\end{array}$ & $\begin{array}{c}\text { Standard } \\
\text { error }\end{array}$ & Elasticity & $\begin{array}{c}\text { Maginal } \\
\text { effect }\end{array}$ & $\begin{array}{c}\text { Standard } \\
\text { error }\end{array}$ & Elasticity \\
\hline Log average wage $\ln \left(W_{i}^{T}\right)$ & $0.055^{* * *} *$ & 0.02 & 0.61 & $0.483 * *$ & 0.20 & 0.48 \\
\hline Expected subsidy $\left(S_{i 0}^{T}\right)$ & $0.258^{*}$ & 0.15 & 2.84 & $2.919 *$ & 1.52 & 1.53 \\
\hline Log expected training cost $\ln \left(C_{i 0}^{T}\right)$ & -0.001 & 0.005 & -0.01 & -0.024 & 0.05 & -0.02 \\
\hline Log number of employees $\ln \left(N_{i}\right)$ & $0.022 * * *$ & 0.003 & 0.24 & $0.123 * * *$ & 0.03 & 0.12 \\
\hline Log Capital & $0.008 * *$ & 0.004 & 0.09 & $0.092 * * *$ & 0.04 & 0.09 \\
\hline \multicolumn{7}{|l|}{ Sector } \\
\hline Agriculture & -0.003 & 0.02 & & -0.115 & 0.18 & \\
\hline Manufacturing and textiles & 0.003 & 0.01 & & 0.008 & 0.08 & \\
\hline Wholesale and retail & -0.004 & 0.01 & & -0.042 & 0.07 & \\
\hline Community, social and other services & 0.001 & 0.01 & & -0.045 & 0.09 & \\
\hline Construction & -0.014 & 0.01 & & -0.131 & 0.10 & \\
\hline Finance & -0.025 & 0.02 & & -0.227 & 0.21 & \\
\hline Hotels & -0.010 & 0.01 & & -0.146 & 0.11 & \\
\hline Information technology & 0.006 & 0.02 & & 0.166 & 0.19 & \\
\hline Constant & & & & $-5.434 * * *$ & 1.51 & \\
\hline $\mathrm{R}^{2}$ & 0.02 & & & 0.06 & & \\
\hline Sample size & 13403 & & & 13392 & & \\
\hline
\end{tabular}

Source: Authors' computation based on the Mauritius training and firm characteristics data set, 2007/2008

Notes: * significant at 10 percent $* *$ significant at 5 percent $* * *$ significant at 1 percent 
Table 4: Total training levies paid and subsidies received in 2007, by firm size and sector cells, in million Mauritian rupees.

\begin{tabular}{|c|c|c|c|c|c|c|c|c|c|c|c|c|}
\hline & \multicolumn{4}{|c|}{ Small 1-9 workers } & \multicolumn{4}{|c|}{ Medium 10-50 workers } & \multicolumn{4}{|c|}{ Large $>50$ workers } \\
\hline & $\begin{array}{c}(1) \\
\text { Levy } \\
\end{array}$ & $\begin{array}{c}(2) \\
\text { Subsidy } \\
\end{array}$ & $\begin{array}{l}(2) /(1) \\
\text { Ratio } \\
\end{array}$ & \begin{tabular}{l|} 
Ratio \\
that \\
Trained* \\
\end{tabular} & $\begin{array}{c}(1) \\
\text { Levy } \\
\end{array}$ & $\begin{array}{c}(2) \\
\text { Subsidy } \\
\end{array}$ & $\begin{array}{c}(2) /(1) \\
\text { ratio } \\
\end{array}$ & $\begin{array}{l}\text { Ratio } \\
\text { that } \\
\text { trained* }\end{array}$ & $\begin{array}{c}(1) \\
\text { Levy } \\
\end{array}$ & $\begin{array}{c}(2) \\
\text { Subsidy } \\
\end{array}$ & $\begin{array}{c}(2) /(1) \\
\text { ratio } \\
\end{array}$ & $\begin{array}{l}\text { Ratio } \\
\text { that } \\
\text { Trained* }\end{array}$ \\
\hline Agriculture & 0.94 & 4.71 & 5.01 & 0.07 & 2.31 & 1.51 & 0.65 & 0.12 & 14.3 & 1.99 & 0.14 & 0.40 \\
\hline $\begin{array}{l}\text { Manufacturing and } \\
\text { textiles }\end{array}$ & 2.66 & 4.83 & 1.82 & 0.08 & 8.28 & 7.88 & 0.95 & 0.14 & 40.3 & 14.10 & 0.35 & 0.41 \\
\hline Wholesale and retail & 3.24 & 10.30 & 3.18 & 0.09 & 4.06 & 2.97 & 0.73 & 0.14 & 11.4 & 3.10 & 0.27 & 0.51 \\
\hline $\begin{array}{l}\text { Community, social } \\
\text { and other services }\end{array}$ & 3.4 & 9.02 & 2.65 & 0.08 & 5.62 & 3.72 & 0.66 & 0.21 & 11.9 & 3.60 & 0.30 & 0.35 \\
\hline Construction & 1.86 & 2.59 & 1.39 & 0.07 & 4.07 & 2.49 & 0.61 & 0.12 & 11.6 & 2.39 & 0.21 & 0.37 \\
\hline Finance & 3.3 & 6.93 & 2.10 & 0.13 & 6.07 & 6.17 & 1.02 & 0.32 & 22.2 & 70.10 & 3.16 & 0.43 \\
\hline $\begin{array}{l}\text { Information } \\
\text { technology }\end{array}$ & 0.98 & 1.67 & 1.71 & 0.12 & 1.92 & 10.70 & 5.57 & 0.31 & 3.39 & 0.62 & 0.18 & 0.60 \\
\hline Transport & 6.86 & 24.60 & 3.59 & 0.08 & 10 & 16.00 & 1.60 & 0.20 & 24.3 & 5.88 & 0.24 & 0.34 \\
\hline
\end{tabular}

Source: Authors' computation based on the Mauritius training and firm characteristics data set, 2007.

*Ratio that trained : number of firms that trained as a fraction of total number of firms in each sector. 
Table 5: Regressions explaining various measures of firm output and growth using predicted intensity of training

\begin{tabular}{|c|c|c|c|c|c|c|}
\hline \multirow[t]{2}{*}{ Variables } & \multicolumn{2}{|l|}{$\begin{array}{c}\text { Log } \\
\text { output }\end{array}$} & \multicolumn{2}{|c|}{ Log wage bill growth } & \multicolumn{2}{|c|}{$\begin{array}{c}\text { Log employmen } \\
\text { growth }\end{array}$} \\
\hline & Coeff & SE & Coeff & SE & Coeff & SE \\
\hline $\begin{array}{l}\text { Log capital } \\
\text { Predicted intensity of } \\
\text { training } \\
\text { Log number of } \\
\text { employees } \\
\text { Sector } \\
\text { Agriculture } \\
\text { Manufacturing and } \\
\text { textiles } \\
\text { Wholesale and retail } \\
\text { Community, social and } \\
\text { other services } \\
\text { Construction } \\
\text { Finance } \\
\text { Hotels } \\
\text { Information technology } \\
\text { Constant }\end{array}$ & \begin{tabular}{|l}
$0.076 * * *$ \\
$0.417 *$ \\
$0.716^{* * * *}$ \\
$-0.554 * * *$ \\
$-0.656 * * *$ \\
$-0.287 * * *$ \\
$-0.751 * * *$ \\
$-0.364 * * *$ \\
$-0.926 * * *$ \\
$-0.976 * * *$ \\
$-0.623 * * *$ \\
$13.308 * * *$ \\
\end{tabular} & $\begin{array}{l}0.007 \\
0.241 \\
0.060 \\
\\
0.164 \\
\\
0.076 \\
0.063 \\
\\
0.081 \\
0.100 \\
0.140 \\
0.076 \\
0.139 \\
0.120 \\
\end{array}$ & $\mid \begin{array}{l}0.020 \\
0.061 \\
0.042^{* *} \\
-0.137 * * * \\
0.018 \\
0.037^{*} \\
0.022 \\
0.106^{* * *} \\
0.096^{* *} \\
0.029 \\
0.162^{* *} \\
0.182 \\
\end{array}$ & $\begin{array}{l}0.015 \\
0.105 \\
0.018 \\
0.052 \\
\\
0.025 \\
0.022 \\
\\
0.025 \\
0.037 \\
0.041 \\
0.037 \\
0.069 \\
0.181 \\
\end{array}$ & \begin{tabular}{|l}
$0.039 * * *$ \\
0.027 \\
$-0.076 * * *$ \\
$-0.095 * * *$ \\
$0.058^{* * *}$ \\
0.006 \\
$-0.036 * *$ \\
$0.073 * * *$ \\
0.009 \\
-0.009 \\
$0.132 * * *$ \\
$-0.503 * * *$ \\
\end{tabular} & $\begin{array}{l}0.009 \\
0.064 \\
0.011 \\
0.032 \\
0.015 \\
0.014 \\
0.015 \\
0.023 \\
0.025 \\
0.022 \\
0.043 \\
0.111 \\
\end{array}$ \\
\hline$\frac{\mathrm{R}^{2}}{\text { Sample size }}$ & $\mid 0.47$ & & $\mid$\begin{tabular}{||l|}
0.01 \\
10563
\end{tabular} & & $\mid$\begin{tabular}{||l}
0.03 \\
10562
\end{tabular} & \\
\hline
\end{tabular}

Source: Authors' computation based on the Mauritius training and firm characteristics data set, 2007.

Notes: * significant at 10 percent $* *$ significant at 5 percent $* * *$ significant at 1 percent 
Appendix 1: Summary Statistics

\begin{tabular}{lcr}
\hline Variable & \multicolumn{2}{c}{ Mean } \\
\hline & & 2007 \\
Firm characteristics & 11.93 & 6.64 \\
Percentage trained & 20.97 & 20.64 \\
Number of Employees & & \\
Grants received (conditional on training) & 154.72 & 99.89 \\
(thousand rupees) & & \\
Grants received (unconditional) & 18.46 & 6.63 \\
(thousand rupees) & 18.06 & 18.23 \\
Levies paid (thousand rupees) & & \\
Accounting Data (million rupees) & 45.90 & 33.00 \\
Sales in 2007 & 19.30 & 18.80 \\
Cost of Capital & & \\
Fraction of firms in & 0.08 & 0.07 \\
Agriculture & 0.14 & 0.14 \\
Manufacturing and textiles & 0.13 & 0.29 \\
Wholesale and retail & 0.14 & 0.14 \\
Community, social and other services & 0.08 & 0.08 \\
Construction & 0.05 & 0.06 \\
Finance & 0.07 & 0.07 \\
Hotels & 0.02 & 0.02 \\
Information technology & 0.28 & 0.11 \\
Transport & &
\end{tabular}

Source: Authors' computation based on the Mauritius training and firm characteristics data set, 2007. 